\title{
Spatio-temporal variability of discards in the fishery of the deep-sea red shrimp Aristeus antennatus in the northwestern Mediterranean Sea: implications for management
}

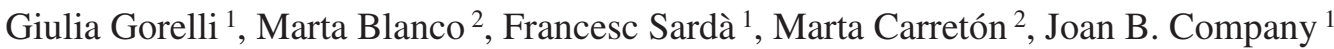 \\ ${ }^{1}$ Institut de Ciències del Mar, CSIC, Passeig Marítim de la Barceloneta 37-49, Barcelona, Spain. \\ E-mail: gorelli@icm.csic.es \\ ${ }^{2}$ Facultad de Biología, Universitat de Barcelona, Avinguda Diagonal 643, Barcelona, Spain.
}

\begin{abstract}
Summary: In this work we analysed the spatio-temporal variability of discards in the fishery of the deep-sea red shrimp Aristeus antennatus in the northwestern Mediterranean Sea. We sampled fishery discards in the fishing grounds of Palamós (the main harbour for this fishery on the Catalan margin), which are located in several areas of a submarine canyon. We found that the discard ratio in this fishery showed a marked seasonal variability, with a maximum in spring and a minimum in summer. Most of the discarded biomass (almost 96\%) were of species with no commercial interest. Within these, the most represented group was elasmobranchs, making up to more than $50 \%$ of total discarded biomass. Our findings show that the landing obligation established by the EU will have a low impact in mitigating discards in this fishery, as the vast majority of discards are non-commercial species that are not specified in the regulation. Alternative management strategies, such as a temporary fishery closure in spring (when the discard ratio reaches its maximum), should be considered in order to preserve the vulnerable ecosystem hosted by the submarine canyon.
\end{abstract}

Keywords: Northwestern Mediterranean; trawl fishery; fishery discards; fisheries impact; deep-sea; Aristeus antennatus.

Variabilidad espacio-temporal de los descartes en la pesquería de la gamba roja de profundidad Aristeus antennatus en el mar Mediterráneo Noroccidental: implicaciones para la gestión

Resumen: En este estudio se analizó la variabilidad espacio-temporal de los descartes en la pesquería de la gamba roja de profundidad Aristeus antennatus en el mar Mediterráneo Noroccidental. Para ello se muestrearon las capturas obtenidas en los caladeros de Palamós (el mayor puerto para esta pesquería en Cataluña), que están localizados en diferentes áreas adyacentes a un cañón submarino. Nuestros resultados demuestran que la proporción de descartes en las capturas de esta pesquería presenta una marcada variabilidad estacional, con un máximo en primavera y un mínimo en verano. La mayoría de la biomasa de los descartes (casi el 96\%) está constituida por especies sin ningún interés comercial. Entre éstas, el grupo más representado es el de los elasmobranquios, que constituye más del 50\% de la biomasa total de los descartes. Nuestros resultados indican que la obligación de desembarcar las capturas establecida por la UE tendrá un impacto bajo en disminuir los descartes en esta pesquería, ya que la gran mayoría de los descartes está constituida por especies no comerciales que no están especificadas en la regulación. Medidas de gestión alternativas, como el establecimiento de una veda en primavera (cuando la proporción de descartes llega a su máximo) deberían considerarse para preservar el ecosistema vulnerable de este cañón submarino.

Palabras clave: Mediterráneo Noroccidental; pesca de arrastre; descartes; impacto de la pesca; mar profundo; Aristeus antennatus.

Citation/Como citar este artículo: Gorelli G., Blanco M., Sardà F., Carretón M., Company J.B. 2016. Spatio-temporal variability of discards in the fishery of the deep-sea red shrimp Aristeus antennatus in the northwestern Mediterranean Sea: implications for management. Sci. Mar. 80(1): 79-88. doi: http://dx.doi.org/10.3989/scimar.04237.24A

Editor: J.A. Cuesta.

Received: March 12, 2015. Accepted: July 31, 2015. Published: December 11, 2015.

Copyright: () 2016 CSIC. This is an open-access article distributed under the Creative Commons Attribution-Non Commercial Lisence (by-nc) Spain 3.0. 


\section{INTRODUCTION}

Fisheries have an impact on the ecosystems at various levels, as fishing operations affect not only the targeted fish stocks but also a number of species that are caught accidently in the fishing gears. These species are thrown back to the sea, dead or alive, and constitute the fishery discards (Catchpole et al. 2005, Kelleher 2005, Bellido et al. 2011). Discarded species may have no commercial interest or may be valuable species that are unmarketable for different reasons (undersized or damaged individuals, exceeded quotas, etc.). The effect of fishing activities on the environment is great, ranging from ecosystem depletion to habitat destruction, and discards account for a great part of the overall impact (Ramsay et al. 1998, Jennings and Kaiser 1998, Sánchez et al. 2000). In fact, up to $60 \%$ of the total catch is discarded in some of the most important European trawl fisheries (STECF 2006). In the last few years, after the establishment of the Ecosystem Approach to Fisheries Management as an integrated approach which considers the effects of fisheries on the whole ecosystem (FAO fisheries glossary, http://www.fao.org/fi/glossary/default.asp), estimating discards and developing ad hoc management strategies have been regarded as a priority (Catchpole and Gray 2010, Bellido et al. 2011, Hilborn 2011). In Europe, discards are currently a hot topic for fisheries management (Catchpole et al. 2005, Johnsen and Eliasen 2011, Sardà et al. 2013, Condie et al. 2014). They form an important part of the reformed Common Fisheries Policy (CFP), which has established a landing obligation that will come into force gradually in the next four years (European Union 2013). The aim of the landing obligation is to reduce wastage in fishing operations while incentivizing discard avoidance. In this context, it is important to consider that discards are highly variable in both space and time (Ye et al. 2000, Uhlmann et al. 2013, Pennino et al. 2014). Extensive research on discards in single fisheries with the identification of factors shaping their spatio-temporal patterns is therefore required in order to improve discard avoidance and selectivity.

In the Mediterranean Sea, trawl fishery is the most important fishery in terms of both volume and economic value of catches (Bas et al. 1984, Abelló et al. 2002). This fishery is generally characterized by high discard ratios and it is responsible for the bulk of discards (Stergiou et al. 1998, Castriota et al. 2001, Carbonell et al. 2003, Sánchez et al. 2004, Tsagarakis et al. 2008). A recent review by Tsagarakis et al. (2013) identified a wide range of discard ratios within Mediterranean trawling fisheries, ranging from $10 \%$ to $90 \%$. Factors acknowledged for affecting discards are various and comprise depth, geographic area, seabed characteristics, season, fishing methods, gear characteristics and cultural factors (Machias et al. 2001, Sartor et al. 2003, Sánchez et al. 2007, Edelist et al. 2011, Pennino et al. 2014). The high diversification of fishing practices and the wide range of environmental characteristics in the Mediterranean Sea place severe difficulties in the way of effective management measures to mitigate discards. This condition is compounded by several major gaps in knowledge (Lleonart and Maynou 2003, Kelleher 2005, Tsagarakis et al. 2013). A greater effort to quantify discards and identify factors affecting and shaping their patterns is therefore required.

In the northwestern Mediterranean Sea, the most economically important deep-sea trawl fishery is the one targeting the red shrimp Aristeus antennatus (Risso, 1816). In the Catalan area (northeast Spain) this fishery operates in fishing grounds allocated along the margins of a series of submarine canyons carved into the continental margin. Submarine canyons create considerable depths close to the coast and increase habitat complexity. They also act as major conduits for the transportation and concentration of organic particles (Heussner et al. 1996, Canals et al. 2006, Puig et al. 2013). These characteristics may favour the abundance, biomass and diversity of benthic and pelagic species in the canyons compared with the open slope (Vetter and Dayton 1999). It has also been observed that the higher habitat heterogeneity and the increased food availability in the canyons provide suitable conditions for recruitment of several species of fish and crustaceans (Sardà et al. 1994b, Stefanescu et al. 1994). The importance of submarine canyons in shaping the benthic community of species in the northwestern Mediterranean Sea was assessed in several studies (Sardà et al. 1994a, Ramirez-Llodra et al. 2008). In particular, the relationship between the topography of the canyons and the red shrimp seasonal migrations was described in detail (Sardà et al. 2003, Tudela et al. 2003, Sardà et al. 2004, Sardà et al. 2009) and is well known to the fishers who direct the fishing effort accordingly (Sardà et al. 1997). The vulnerability of these environments to fishing activities has also been pointed out (Ramirez-Llodra et al. 2010). In fact, as deep-sea ecosystems, they are characterized by long-lived species with slow growth, late age of maturity and low fecundity, which make them particularly sensitive to the impact of human activities (Koslow et al. 2000). However, no research on the role of the submarine canyons in shaping patterns of fishery discards has been performed so far.

The aim of this work was to broaden our knowledge of fishery discards in the vulnerable environment of the deep sea, which is important for fishery management both at European and local level. In particular, we investigate the spatio-temporal discard patterns associated with a submarine canyon in the fishery of the red shrimp in the northwestern Mediterranean Sea. The canyon considered is the Palamós Canyon (Fig. 1). The canyon head, wall and open margin of this canyon are the most heavily trawled fishing grounds for this species in the area, with the Palamós trawling fleet landing about 30\% of red shrimp in Catalonia on a yearly average (data source: Official fishery statistics from the Catalan government). Since 2013 the red shrimp fishery in Palamós has been regulated by a local management plan developed within a co-management framework between fishermen, scientists, local administration and NGOs (BOE 2013). Management measures aim to increase the fishery sustainability, paying particular attention to reducing fishing pressure on small-sized individuals of the target species. These measures include a temporary fishery closure at the canyon head (where shoals of shrimp recruits con- 


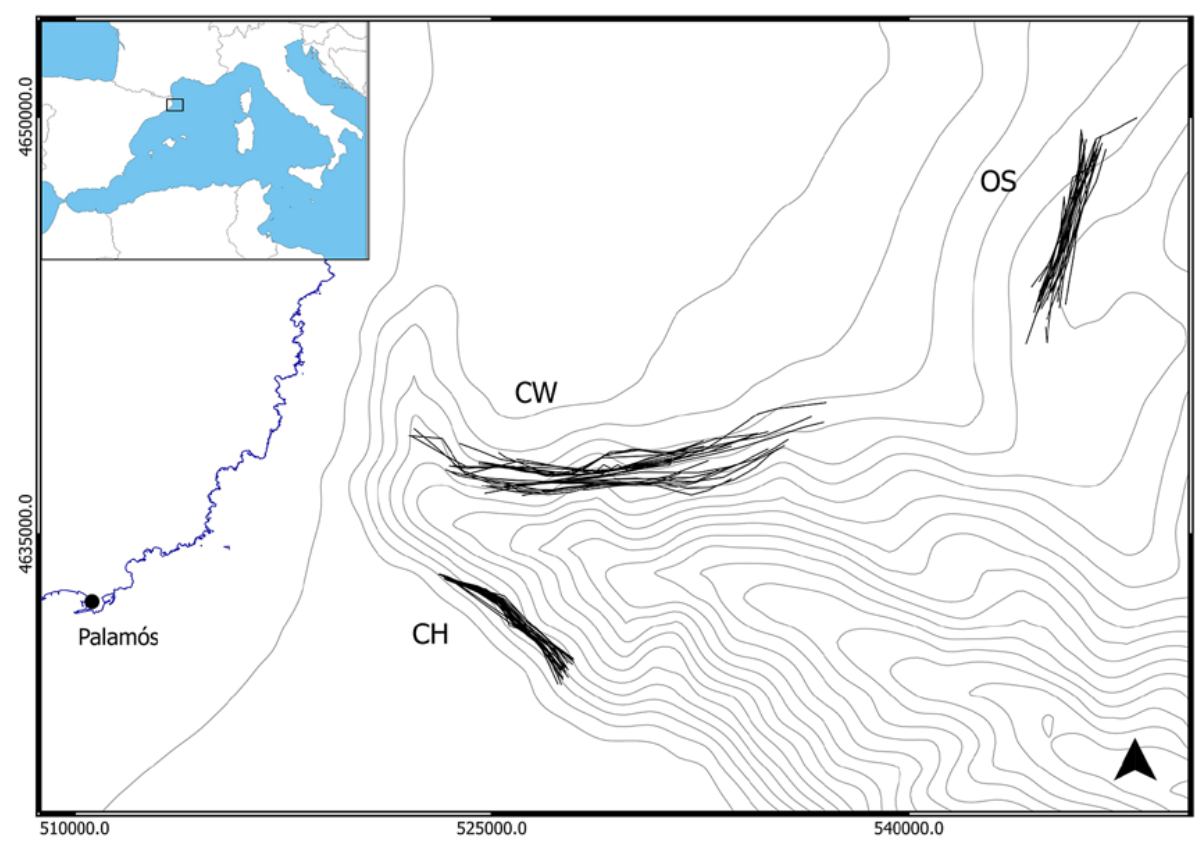

Fig. 1. - Map representing the Palamós canyon and the three main fishing grounds sampled in this study $(\mathrm{CH}$, canyon head; $\mathrm{CW}$, canyon wall; OS, open slope). Tracks of the sampling tows are shown in the map. Coastline is in blue and bathymetry is displayed every $100 \mathrm{~m}$.

centrate) in winter and an increase in gear selectivity. A further improvement in the management plan would be to include ad hoc spatio-temporal management measures to mitigate discards. For this purpose, the specific questions addressed in this work were (i) whether the Palamós submarine canyon and/or the season of the year have an effect on the discard ratio in the fishery studied; and (ii) whether there is a seasonal or spatial variability in discards composition. In order to answer these questions, we analysed the composition of catches during a twoyear sampling onboard a commercial trawler targeting red shrimp in the Palamós canyon.

\section{MATERIALS AND METHODS}

Data were collected on a monthly basis from January 2012 to December 2013, during commercial fishing trips onboard a red shrimp trawler of the Palamós fleet. During each trip we sampled three areas of the Palamós canyon corresponding to the main fishing grounds for this fishery in Catalonia. These areas were the canyon head (average depth, $426 \mathrm{~m}$; total number of tows, 28), the canyon wall (average depth, $504 \mathrm{~m}$; total number of tows, 28) and the open slope, i.e. the area just outside the canyon (average depth, $602 \mathrm{~m}$; total number of tows, 26) (Fig. 1). The average tow trawled $0.2 \mathrm{~km}^{2}$ at the canyon head, $0.3 \mathrm{~km}^{2}$ at the canyon wall and 0.2 $\mathrm{km}^{2}$ on the open slope. The start and end position of each tow, as well as the horizontal opening of the net's mouth, were identified by SCANMAR sensors mounted on the trawl's mouth. These data allowed calculation of the area sampled. After each tow fishermen sorted species into three main categories: target (A. antennatus), by-catch (non-target species of commercial interest) and discards (species with no commercial interest and/or undersized or damaged individuals of commercial species). We recorded the total weight of the commercial yield onboard, while discarded species were preserved in field coolers for further analysis. Once in the lab, the samples were sorted to species level or to the smallest possible taxonomical level. The biomass and abundance of discards were calculated per taxonomical group and standardized per square kilometre trawled.

Differences in the total weight of discards between fishing grounds and seasons were tested by two-way crossed ANOVA on log-transformed data and post-hoc pairwise Tukey test. Before ANOVA was applied (here and in the following analysis) data were tested for normality and homoscedasticity using Shapiro-Wilk's and Bartlett's test, respectively. The discard ratio per tow was calculated as:

$$
\text { Discard ratio }=\frac{\text { Discards weight }}{\text { Discards weight }+ \text { Commercial catch weight }}
$$

Two-way crossed ANOVA and post-hoc Tukey tests were performed on log-transformed data in order to test the effect of fishing ground and season on the discard ratios. Species recovered in the discards were grouped into classes, and differences in abundance and biomass of individual classes were tested by two-way crossed ANOVA. The abundance of the discarded species in each tow was used to calculate two diversity indices: total number of species $(\mathrm{S})$ and $\mathrm{N}_{90}$ diversity index. The $\mathrm{N}_{90}$ diversity index was proposed by Farriols et al. (2015). It uses the results of the SIMPER analysis (Clarke and Warwick 2001) and a jackknife resampling to work out the average and dispersion of the number of species contributing to the $90 \%$ similarity within each group of samples analysed. Therefore, the $\mathrm{N}_{90}$ takes into account both number of species and community structure for its calculation. It was also shown to be able to detect loss of diversity due to fishing impact where other diversity indices failed (Farri- 
Table 1. - List of the most common species in the discards (accounting for $99 \%$ of total abundance and $95 \%$ of total biomass) in the four seasons of the year (Win, winter; Spr, spring; Sum, summer; Aut, autumn) and the three different fishing grounds (CH, canyon head; $\mathrm{CW}$ canyon wall; OS, open slope).

\begin{tabular}{|c|c|c|c|c|c|c|c|c|}
\hline \multirow{2}{*}{ Class } & \multirow[b]{2}{*}{ Species } & \multicolumn{7}{|c|}{ Average abundance (Individuals $\mathrm{km}^{-2}$ ) } \\
\hline & & Win & Spr & Sum & Aut & $\mathrm{CH}$ & CW & OS \\
\hline \multirow[t]{3}{*}{ Chondrichthyes } & Galeus melastomus & 28.8 & 80.7 & 10.5 & 44.6 & 19.9 & 35.5 & 87.0 \\
\hline & Scyliorhinus canicula & 14.2 & 22.9 & 9.4 & 23.0 & 29.0 & 16.4 & 8.5 \\
\hline & Etmopterus spinax & 2.4 & 4.2 & 0.9 & 3.4 & 3.4 & 0.0 & 5.7 \\
\hline \multirow{25}{*}{ Actinopterygii } & Lampanyctus crocodilus & 30.3 & 142.9 & 47.7 & 42.2 & 41.4 & 88.6 & 100.1 \\
\hline & Trachyrincus scabrus & 14.4 & 29.8 & 3.5 & 20.0 & 22.4 & 23.5 & 8.3 \\
\hline & Lepidion lepidion & 16.0 & 25.1 & 5.2 & 2.8 & 8.5 & 13.6 & 18.1 \\
\hline & Capros aper & 0.0 & 32.3 & 4.3 & 1.5 & 36.5 & 1.2 & 0.0 \\
\hline & Notacanthus bonaparte & 5.6 & 2.8 & 1.3 & 30.1 & 0.9 & 10.6 & 17.7 \\
\hline & Nezumia aequalis & 9.1 & 15.2 & 1.1 & 7.6 & 4.2 & 6.8 & 16.4 \\
\hline & Lepidopus caudatus & 2.9 & 14.6 & 5.4 & 4.8 & 5.0 & 15.3 & 2.7 \\
\hline & Mora moro & 5.9 & 5.7 & 3.8 & 14.7 & 0.9 & 4.5 & 17.9 \\
\hline & Gadiculus argenteus & 0.8 & 0.9 & 0.0 & 23.8 & 1.8 & 9.6 & 7.1 \\
\hline & Conger conger & 4.5 & 4.9 & 4.3 & 6.3 & 2.5 & 5.7 & 7.0 \\
\hline & Phycis blennoides & 0.3 & 10.3 & 4.2 & 1.4 & 1.7 & 7.4 & 5.8 \\
\hline & Stomias boa boa & 3.4 & 3.9 & 5.2 & 6.9 & 6.4 & 2.8 & 5.7 \\
\hline & Coelorhynchus sp. & 3.1 & 8.9 & 0.8 & 1.3 & 9.0 & 1.7 & 1.6 \\
\hline & Symphurus sp. & 0.8 & 0.0 & 0.2 & 14.8 & 0.0 & 8.0 & 2.9 \\
\hline & Lepidorhombus boscii & 1.2 & 4.5 & 3.0 & 3.6 & 6.0 & 3.5 & 0.4 \\
\hline & Chauliodus sloani & 0.5 & 1.5 & 8.1 & 2.2 & 0.8 & 1.9 & 6.9 \\
\hline & Helicolenus dactylopterus & 3.6 & 1.3 & 1.9 & 1.3 & 4.4 & 0.4 & 0.8 \\
\hline & Hoplostethus mediterraneus & 1.2 & 1.8 & 1.9 & 2.1 & 2.8 & 1.1 & 1.5 \\
\hline & Antonogadus megalokynodon & 0.2 & 0.0 & 0.0 & 6.1 & 0.0 & 4.3 & 0.0 \\
\hline & Epigonus sp. & 0.0 & 0.1 & 0.4 & 4.0 & 0.0 & 2.1 & 1.2 \\
\hline & Argyropelecus hemigymnus & 0.0 & 0.0 & 0.0 & 3.9 & 0.2 & 0.0 & 2.8 \\
\hline & Arctozenus risso & 0.0 & 0.0 & 2.3 & 0.9 & 0.2 & 1.6 & 0.4 \\
\hline & Alepocephalus rostratus & 1.8 & 0.6 & 0.7 & 0.3 & 0.7 & 0.6 & 1.0 \\
\hline & Myctophidae sp. & 1.4 & 0.0 & 0.0 & 1.6 & 0.2 & 1.1 & 0.5 \\
\hline & Micromesistius poutassou & 1.0 & 0.6 & 0.5 & 0.0 & 0.4 & 0.5 & 0.5 \\
\hline \multirow[t]{15}{*}{ Malacostraca } & Pasiphaea multidentata & 22.3 & 3.9 & 4.8 & 1431.9 & 9.0 & 122.6 & 1001.0 \\
\hline & Pasiphaea sivado & 44.7 & 4.0 & 28.6 & 29.6 & 43.7 & 23.6 & 0.0 \\
\hline & Procesa sp. & 1.2 & 2.7 & 0.0 & 62.8 & 0.5 & 13.5 & 37.1 \\
\hline & Plesionika martia & 0.6 & 2.5 & 0.4 & 52.9 & 0.7 & 12.5 & 29.9 \\
\hline & Solenocera membranacea & 0.0 & 1.2 & 0.1 & 42.6 & 0.0 & 30.2 & 0.0 \\
\hline & Meganyctiphanes norvegica & 0.0 & 0.0 & 0.0 & 41.9 & 0.0 & 28.4 & 0.0 \\
\hline & Sergestes arcticus & 0.0 & 0.0 & 0.0 & 25.1 & 0.0 & 3.4 & 15.9 \\
\hline & Polycheles typhlops & 4.8 & 6.6 & 2.3 & 9.6 & 1.4 & 10.0 & 6.2 \\
\hline & Pleisionika edwardsii & 11.5 & 3.6 & 0.0 & 0.0 & 3.0 & 1.5 & 5.3 \\
\hline & Nephrops norvegicus & 1.0 & 0.9 & 0.0 & 4.6 & 0.0 & 4.1 & 0.5 \\
\hline & Pontocaris lacazei & 0.0 & 1.3 & 0.9 & 1.7 & 0.0 & 2.7 & 0.4 \\
\hline & Paromola cuvieri & 2.6 & 1.1 & 0.3 & 0.3 & 1.9 & 0.7 & 0.3 \\
\hline & Liocarcinus sp. & 0.0 & 0.1 & 1.0 & 1.4 & 0.7 & 1.2 & 0.0 \\
\hline & Parapenaeus longirostris & 0.0 & 1.7 & 0.0 & 0.0 & 1.8 & 0.0 & 0.0 \\
\hline & Pagurus alatus & 1.8 & 0.4 & 0.0 & 0.5 & 0.2 & 0.3 & 1.3 \\
\hline \multirow[t]{9}{*}{ Cephalopoda } & Histiotheutis reversa & 2.2 & 0.2 & 6.3 & 5.9 & 1.3 & 3.0 & 6.1 \\
\hline & Eledone cirrhosa & 5.8 & 2.0 & 1.4 & 0.0 & 1.8 & 3.3 & 0.6 \\
\hline & Histiotheutis bonelli & 0.5 & 3.1 & 0.8 & 0.2 & 0.7 & 0.6 & 3.2 \\
\hline & Sepiola rondeletii & 0.0 & 0.5 & 1.2 & 2.2 & 0.8 & 1.9 & 0.2 \\
\hline & Todarodes sagittatus & 0.5 & 1.4 & 0.0 & 1.3 & 1.0 & 1.3 & 0.3 \\
\hline & Ommastrephidae sp. & 1.7 & 0.9 & 0.3 & 0.3 & 1.4 & 0.1 & 0.8 \\
\hline & Bathypolypus sponsalis & 1.2 & 0.3 & 1.3 & 0.5 & 0.4 & 0.6 & 1.2 \\
\hline & Octopus salutii & 1.1 & 0.8 & 0.2 & 0.0 & 0.7 & 0.6 & 0.3 \\
\hline & Ilex condeitti & 1.3 & 0.0 & 0.0 & 1.2 & 0.2 & 1.2 & 0.0 \\
\hline \multirow{2}{*}{ Thaliacea } & Pyrosoma atlanticum & 0.0 & 5.0 & 0.0 & 2.4 & 0.2 & 0.2 & 7.1 \\
\hline & Salpa sp. & 5.4 & 10.4 & 0.0 & 0.0 & 10.8 & 1.8 & 0.8 \\
\hline
\end{tabular}

ols et al. 2015). The index units, number of species, are straightforward and easy to interpret. Differences in $\mathrm{S}$ and $\mathrm{N}_{90}$ between seasons and fishing grounds were tested by two-way crossed ANOVA and Kruskal-Wallis tests and by post-hoc pairwise tests, respectively. Prior to calculation of $\mathrm{N}_{90}$, abundance data were square-root transformed in order to downweight the contribution of the most abundant species to the results (Clarke and Warwick 2001).

Multivariate analyses were performed using the PRIMER software (Clarke and Gorley 2006). Species abundance was used to calculate the Bray-Curtis similarity index between tows. Data were square-root transformed prior to analysis. The similarities within each fishing ground and season in the species composition of discards were explored by a multidimensional ordination plot (MDS). Differences between fishing grounds and seasons in the species composition of discards were tested by ANOSIM, and SIMPER was employed to detect the species accounting for any significant difference.

\section{RESULTS}

In this study, a total of 94 species were found in the discards during sampling. Table 1 shows a list of the most common species found, i.e. those accounting for nearly $99 \%$ of total abundance and $95 \%$ of total bio- 


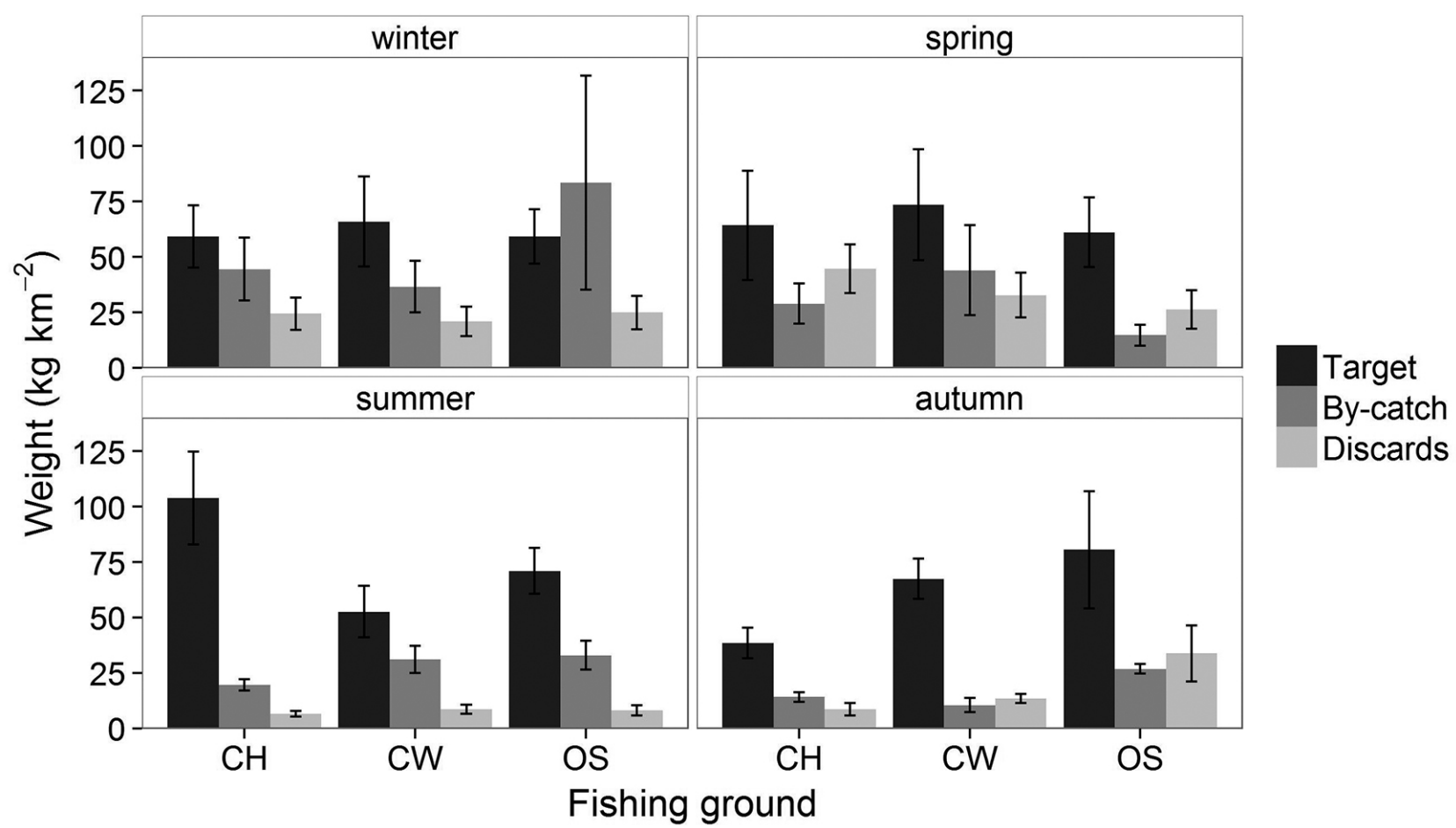

Fig. 2. - Average weight $\left(\mathrm{kg} \mathrm{km}^{-2}\right)$ and standard error of discards, target species and bycatch species in the catches shown per season and fishing ground ( $\mathrm{CH}$, canyon head; $\mathrm{CW}$, canyon wall; OS, open slope).

mass. Regarding the remaining $5 \%$ of biomass, $62.3 \%$ belonged to one species of Elasmobranchia (kitefin shark Dalatias licha), $4.6 \%$ to one species of Holocephali (rabbit fish Chimaera monstrosa), 21.2\% to various species of the class Cephalopoda, $10 \%$ to Actinopterygii, $0.8 \%$ to Gastropoda, $0.7 \%$ to Malacostraca and $0.4 \%$ to Echinoidea. There were no discards of the target species A. antennatus, as there is no minimum landing size (MLS) or catch quota associated with this resource, and any damaged individual was consumed by the fishing crew. Discards of commercial species were limited to a few undersized or damaged specimens of pink glass shrimp (Pasiphaea multidentata), greater fork-beard (Phycis blennoides), Norway lobster (Nephrops norvegicus), blue whiting (Micromesistius poutassou) and European hake (Merluccius merluccius). These species accounted for less than $4.1 \%$ of total discarded biomass. The commercial fraction of the fishery comprised the target species A. antennatus and a few by-catch species, mainly Phycis blennoides, anglerfish Lophius piscatorius, Micromesistius poutassou, Pasiphaea multidentata and Merluccius merluccius. The total weight of discards ranged between 1 and $109 \mathrm{~kg}$ per $\mathrm{km}^{2}$ trawled, while the commercial yield ranged between 9 and $331 \mathrm{~kg}$ per $\mathrm{km}^{2}$ (Fig. 2). The biomass of discards per $\mathrm{km}^{2}$ showed a significant decrease in summer compared with the other seasons of the year (ANOVA, $\mathrm{F}=11.821, \mathrm{df}=3, \mathrm{P}<0.001$ ). No significant differences were detected between fishing grounds (Fig. 3A). The discard ratios ranged between 0.21 and 0.97 , with a significant decrease in summer (Kruskal-Wallis, $\mathrm{K}-\mathrm{S}=18.878, \mathrm{df}=3, \mathrm{p}<0.0001$ ) and no significant difference between fishing grounds (Fig. 3B). The most represented class in terms of biomass in
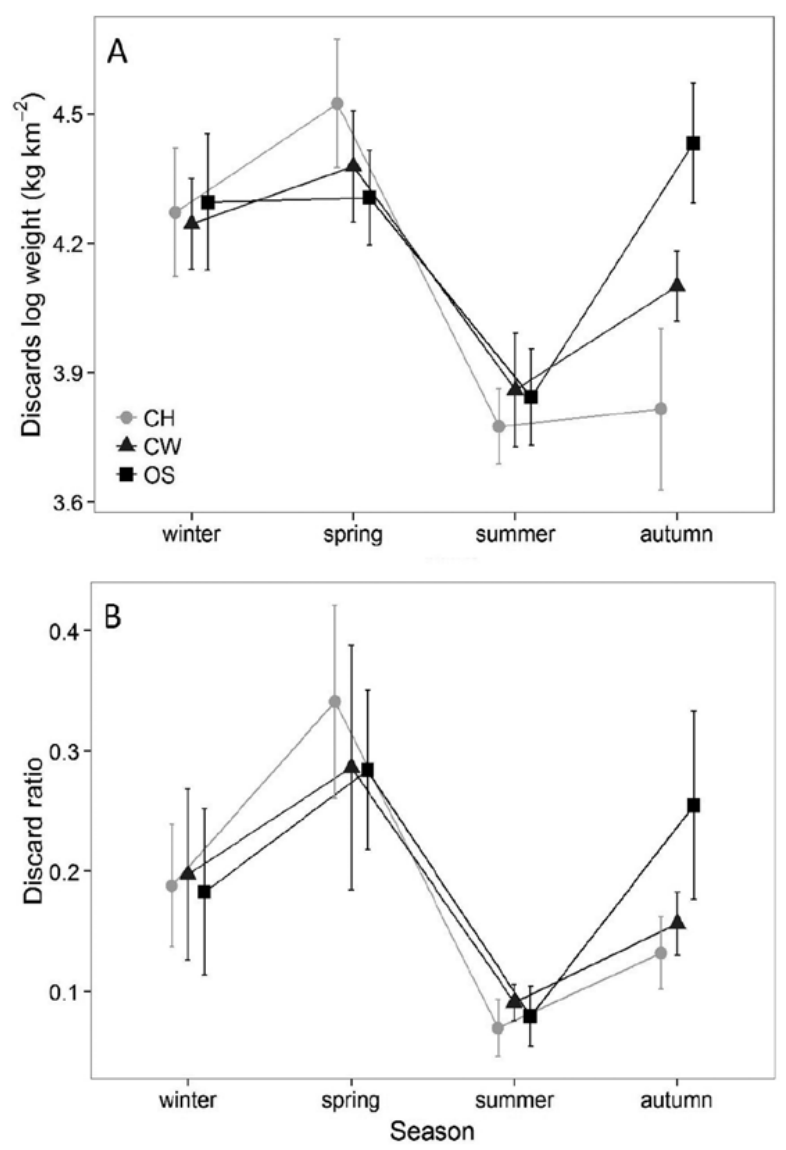

Fig. 3. - Average value and standard error of log-transformed discard weight (A) and discard ratio (B) per season and fishing ground $(\mathrm{CH}$, canyon head; $\mathrm{CW}$, canyon wall; $\mathrm{OS}$, open slope). 


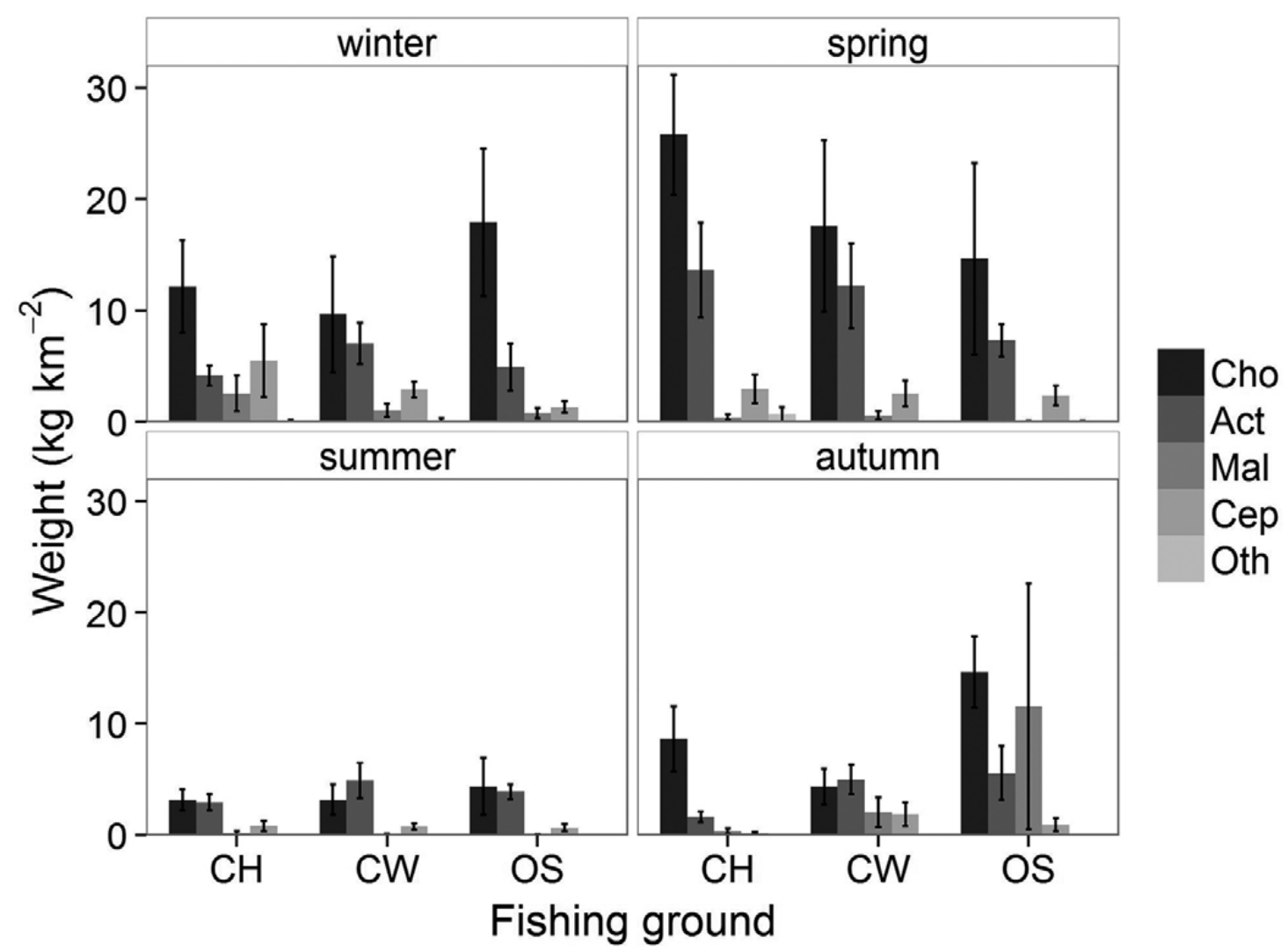

Fig. 4. - Average biomass $\left(\mathrm{kg} \mathrm{km}^{-2}\right)$ and standard error of the different classes of organisms found in the discards per season and fishing ground (Cho, Chondrichthyes; Act, Actinopterygii; Mal, Malacostraca; Cep, Cephalopoda; Oth, other; CH, canyon head; CW, canyon wall; OS, open slope).

Table 2. - Results of two-way ANOVA testing the effect of season and fishing ground on the abundance and biomass of the most common classes of organisms found in the discards. Significance level: $*=p<0.05 ; * *=p<0.01 ; * * *=p<0.001$

\begin{tabular}{|c|c|c|c|c|c|c|c|c|}
\hline Variable & Class & Factor & df & Sum sq. & Mean sq. & F value & $\mathrm{p}$ & Sig. \\
\hline \multirow[t]{16}{*}{ Biomass } & \multirow[t]{4}{*}{ Chondrichthyes } & Season & 3 & 4.678 & 1.5595 & 4.798 & 0.00462 & $* *$ \\
\hline & & Fishing ground & 2 & 1.199 & 0.5996 & 1.845 & 0.16693 & \\
\hline & & Season*Fishing ground & 6 & 1.666 & 0.2776 & 0.854 & 0.53370 & \\
\hline & & Residuals & 60 & 19.502 & 0.3250 & & & \\
\hline & \multirow[t]{4}{*}{ Actinopterygii } & Season & 3 & 2.892 & 0.9640 & 6.006 & 0.00115 & $* *$ \\
\hline & & Fishing ground & 2 & 0.391 & 0.1957 & 1.219 & 0.30239 & \\
\hline & & Season*Fishing ground & 6 & 0.716 & 0.1194 & 0.744 & 0.61641 & \\
\hline & & Residuals & 63 & 10.111 & 0.1605 & & & \\
\hline & \multirow[t]{4}{*}{ Malacostraca } & Season & 3 & 14.45 & 4.817 & 3.430 & 0.0221 & $*$ \\
\hline & & Fishing ground & 2 & 4.15 & 2.074 & 1.477 & 0.2361 & \\
\hline & & Season*Fishing ground & 6 & 3.58 & 0.597 & 0.425 & 0.8598 & \\
\hline & & Residuals & 64 & 89.89 & 1.405 & & & \\
\hline & \multirow[t]{4}{*}{ Cephalopoda } & Season & 3 & 13.20 & 4.398 & 2.631 & 0.0575 & \\
\hline & & Fishing ground & 2 & 5.88 & 2.938 & 1.757 & 0.1807 & \\
\hline & & Season*Fishing ground & 6 & 7.23 & 1.206 & 0.721 & 0.6339 & \\
\hline & & Residuals & 64 & 106.99 & 1.672 & & & \\
\hline \multirow[t]{16}{*}{ Abundance } & \multirow[t]{4}{*}{ Chondrichthyes } & Season & 3 & 3.381 & 1.1269 & 6.396 & 0.00078 & *** \\
\hline & & Fishing ground & 2 & 1.247 & 0.6234 & 3.538 & 0.03527 & $*$ \\
\hline & & Season*Fishing ground & 6 & 0.956 & 0.1593 & 0.904 & 0.49826 & \\
\hline & & Residuals & 60 & 10.571 & 0.1762 & & & \\
\hline & \multirow{4}{*}{ Actinopterygii } & Season & 3 & 3.905 & 1.3018 & 8.353 & 0.0001 & $* * *$ \\
\hline & & Fishing ground & 2 & 0.898 & 0.4489 & 2.880 & 0.0635 & \\
\hline & & Season*Fishing ground & 6 & 0.862 & 0.1437 & 0.922 & 0.4852 & \\
\hline & & Residuals & 63 & 9.818 & 0.1558 & & & \\
\hline & \multirow[t]{4}{*}{ Malacostraca } & Season & 3 & 11.56 & 3.855 & 5.326 & 0.00244 & $* *$ \\
\hline & & Fishing ground & 2 & 2.83 & 1.414 & 1.953 & 0.15015 & \\
\hline & & Season*Fishing ground & 6 & 4.22 & 0.703 & 0.971 & 0.45221 & \\
\hline & & Residuals & 64 & 46.32 & 0.724 & & & \\
\hline & \multirow[t]{4}{*}{ Cephalopoda } & Season & 3 & 0.578 & 0.1926 & 0.699 & 0.556 & \\
\hline & & Fishing ground & 2 & 0.757 & 0.3784 & 1.374 & 0.261 & \\
\hline & & Season*Fishing ground & 6 & 1.226 & 0.2044 & 0.742 & 0.618 & \\
\hline & & Residuals & 64 & 17.631 & 0.2755 & & & \\
\hline
\end{tabular}



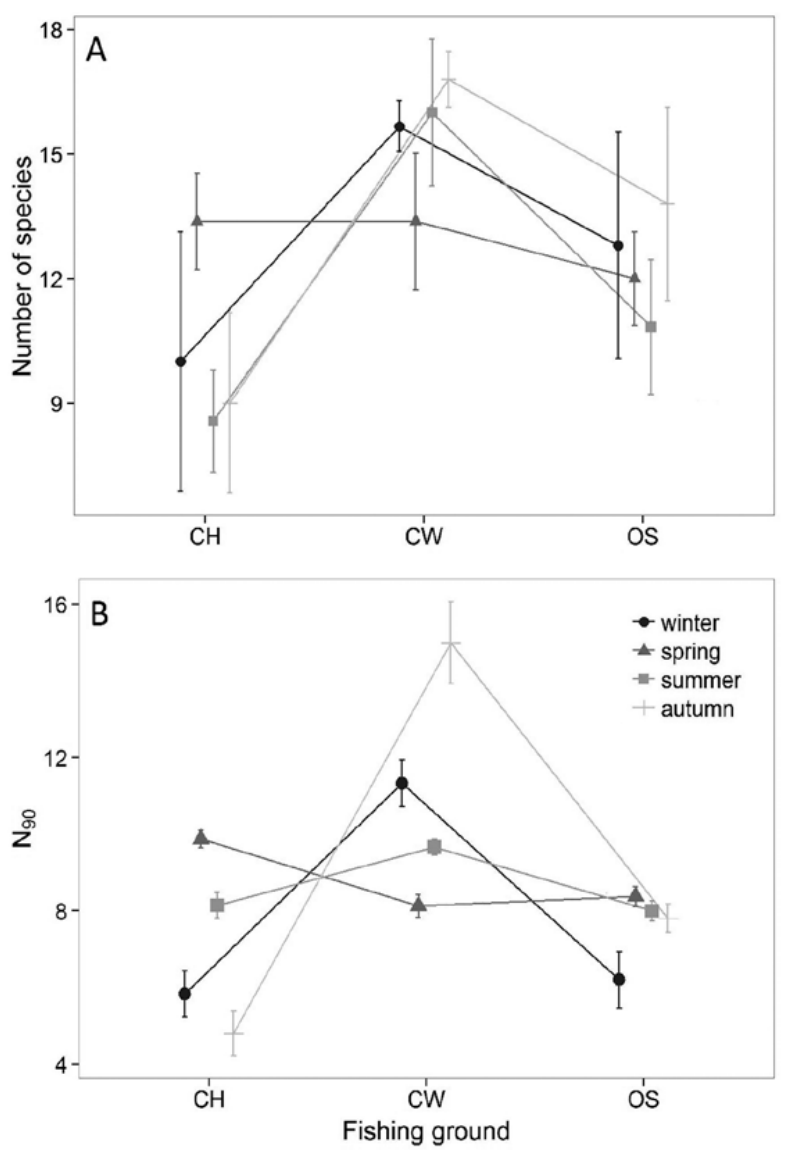

Fig. 5. - Average value and standard error of total number of species (A) and $\mathrm{N}_{90}$ diversity index (B) in the discards per season and fishing ground $(\mathrm{CH}$, canyon head; $\mathrm{CW}$, canyon wall; $\mathrm{OS}$, open slope).

the discards was Chondrichthyes (53\% of the total), followed by Actinopterygii (30\%), Cephalopoda (9.1\%) and Malacostraca (6.5\%) (Fig. 4). Classes Echinoidea, Gastropoda and Thaliacea accounted together for less than $1.5 \%$ of total discarded biomass and were grouped into the class "other". Biomass and abundance of all classes except for Cephalopoda showed significant differences between seasons (Table 2). Abundance of Chondrichthyes also displayed a significant effect of fishing ground, with individuals being more abundant on the open slope. A total of five individuals of kitefin shark (Dalatias licha), a species classified as near threatened by the IUCN (2014), were found in the discards (two individuals on the open slope and three at the canyon head).

The number of species in the discards ranged between 2 and 24 and was significantly higher in the canyon wall than in the other fishing grounds (ANO$\mathrm{VA}, \mathrm{F}=7.658, \mathrm{df}=2, \mathrm{p}<0.01$ ) (Fig. $5 \mathrm{~A}$ ). The $\mathrm{N}_{90}$ index ranged between 4 and 18 and differences between fishing grounds, in particular between the canyon wall and the others, were significant (Kruskal-Wallis, $\mathrm{K}-\mathrm{S}=22.5718, \mathrm{df}=2, \mathrm{p}<0.05)$. As displayed in Figure $5 \mathrm{~B}$, the $\mathrm{N}_{90}$ was significantly higher in the canyon wall in winter and autumn. An interaction between the factors fishing ground and season seems to be present, although the Kruskal-Wallis test does not allow test-

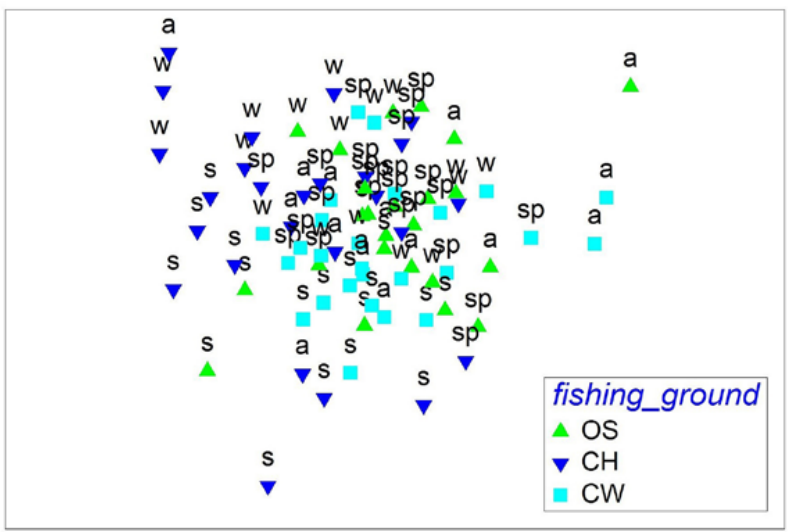

Fig. 6. - MDS ordination plot of the single hauls $(\mathrm{CH}$, canyon head; $\mathrm{CW}$, canyon wall; OS, open slope; w, winter; sp, spring; s, summer; a, autumn).

ing for it and, due to non-normality of data, a two-way ANOVA could not be employed. The MDS ordination plot, where the two-dimensional distance between tows reflects the Bray-Curtis similarity index, is shown in Figure 6. ANOSIM detected significant differences in the species composition of discards both between seasons and fishing grounds. In particular, the pairwise test highlighted significant differences between spring and all other seasons $(\mathrm{p}<0.001)$, and between the canyon head and the canyon wall and open slope $(\mathrm{p}<0.05$ and $\mathrm{p}<0.001$, respectively).

The most common species in the discards at all seasons and fishing grounds were the jewel lanternfish (Lampanyctus crocodilus), the blackmouth catshark (Galeus melastomus) and the small spotted catshark (Scylorhinus canicula). Spring discards were characterized by higher abundance of these species compared with the other seasons, and a relatively high abundance of the less common actinopterygian species Trachyrincus scabrus, Lepidion lepidion, $\mathrm{Ne}$ zumia aequalis and Lepidopus caudatus. On the other hand, the decapod crustacean Pasiphaea multidentata, actinopterygians Notacanthus bonaparte, Mora moro and Gadiculus argenteus were particularly abundant in autumn. According to the SIMPER analysis, the top 10 species contributing to the differences in the species composition of discards between the canyon head and the canyon wall were the chondrichthyans Scylorhinus canicula, the actinopterygians Capros aper, Pasiphaea sivado, more abundant at the canyon head, and Lampanyctus crocodilus, Trachyrinchus scabrus, Galeus melastomus, Pasiphea multidentata, and the decapod crustaceans Polycheles typhlops, Lepidion lepidion and Lepidopus caudatus, more abundant in the canyon wall. These species accounted for $44 \%$ of the total differences. The top 10 species accounting for $47 \%$ of the differences between the canyon head and the open slope were Scylorhinus canicula, Trachyrincus scabrus, Capros aper, the actinopterygian Stomias boa boa, more abundant at the canyon head, and Lampanyctus crocodilus, Galeus melastomus, Pasiphaea multidentata, Mora moro, Nezumia aequalis, Lepidion lepidion, more abundant on the open slope. 


\section{DISCUSSION}

The average discard ratio observed in this study was 0.2 , similar to values obtained in other studies on deep-sea trawl fisheries in the northwestern Mediterranean Sea (Sartor et al. 2003, Sánchez et al. 2004). In fact, a discard ratio of 0.2 was found in a previous study in the Catalan area and a discard ratio ranging between 0.2 and 0.3 was found in the Tyrrhenian Sea. The relatively low discard ratio found in these fisheries is associated with the high depths where they operate ( $>400 \mathrm{~m}$ ). Trawl fisheries operating on the continental shelf at lower depths are usually associated with higher discard ratios (Sánchez et al. 2004, Tsagarakis et al. 2013). In the Balearic Islands, the discard ratio in deepsea shrimp fisheries was a little bit higher, around 0.4, but diminished with depth (Moranta et al. 2000). Our results also highlighted a marked seasonal variability in the discard ratios. Their value was particularly high in spring, with $80 \%$ of discard ratios higher than 0.4 being observed in late March, April and May. These values were mostly due to the occurrence of a high discarded biomass in these months. Moreover, yields of the target species $A$. antennatus can be considerably reduced in the same months, contributing to the resulting high discard ratios. In fact, submarine currents (cascading) that occur in the study area in late winter/early spring can be particularly strong in some years and have been associated with extremely low catches of $A$. antennatus (Company et al. 2008). On the other hand, particularly low discard ratios were observed in summer. This is a favourable time for the fishery of the red shrimp in Catalonia, due to the high yields of the target species and the greater proportion of big individuals in the catches, which are sold at a higher price in the market (Sardà et al. 1994b).

The multivariate analysis showed that the species composition of discards at the canyon head was significantly different from that in the other fishing grounds, and the highest number of species was found at the canyon wall. Similar patterns in the community of species of the Blanes submarine canyon (a few miles south of the Palamós canyon, supporting a similar fishing activity) were highlighted in a previous study by RamirezLlodra et al. (2010). In fact, these authors found significant differences in the benthic community between locations inside and outside the canyon, and they also found that diversity was higher inside the canyon than on the open slope. Similarly to our study, these authors found a low or null abundance of sessile faunal groups, such as echinoderms, gastropods, bivalves and cnidarian. These groups were found to be common in other submarine canyons in the Catalan area (Cartes 1998, Ramirez-Llodra et al. 2008) but are particularly sensitive to fishing pressure with consistent loss of abundance in heavily trawled areas (Auster et al. 1996, De Juan et al. 2013). The fact that in this study we found that diversity of species at the canyon head, the most embedded area of the canyon, was reduced compared with diversity at the canyon wall might be an indicator of fishing impact in this highly productive and heavily trawled area. In fact, the canyon head is the closest fishing ground to the coast and is the principal target of fishing boats in winter and early spring when the weather is rough and shoals of red shrimp concentrate in this area (Tudela et al. 2003).

It stands out from our results that the vast majority of discards in this fishery $(\approx 96 \%)$ consisted of noncommercial species belonging to a variety of taxa. In particular, more than half $(53 \%)$ of the discards were Chondrichthyes, which are vulnerable species because of their biological traits and k-selection life history (Pennino et al. 2013). The discards include the nearly threatened species Dalatias licha (IUCN 2014). The mortality introduced at various levels of the ecosystem by the catch of unwanted species might imply serious consequences for the health of the submarine canyon's communities. For this reason, effective management to reduce discards in this fishery is required.

When the landing obligation required by the CFP of the EU comes into force, all catches of commercial species managed through catch quotas or MLS (except for those used as live baits) will be subject to mandatory landing (European Union 2013). In the Mediterranean, as there are no fisheries managed through catch quotas, except for the blue fin tuna, the landing obligation will apply to species managed through MLS at EU level (Article 15 of Regulation (EU) No 1380/2013, [European Union 2013]). However, according to our findings, this regulation will have an extremely low impact on the fishery studied, as nearly $96 \%$ of the total discards consist of non-commercial species that are not affected by the landing obligation at all. Our results show that the landing obligation will only prevent discarding of an average of $0.9 \mathrm{~kg} \mathrm{~km}^{-2}$ of undersized or damaged individuals of few commercial species. Our study confirms that the main reason for discarding in the Mediterranean Sea is the lack of commercial interest in many of the species caught (Sánchez et al. 2004, Tsagarakis et al. 2013, Catchpole et al. 2013). For this reason, the benefits of implementing the landing obligation in the Mediterranean Sea have been questioned by other authors (Sardà et al. 2013, Catchpole et al. 2013, García-Rivera et al. 2015).

If reducing discards is a priority within the CFP, a different management strategy, not solely based on commercial species, must be designed in order to address the particular characteristics of Mediterranean fisheries. In northern Europe, ad hoc spatio-temporal fishery closures have been highlighted as one of the most efficient management strategies for mitigating discards (Catchpole et al. 2005, Catchpole and Gray 2010, Johnsen et al. 2011, Condie et al. 2014). For example, the Norwegian fisheries in the Barents Sea (Bjørnar 1996) successfully reduced the discard ratio of haddock and cod by implementing a system of realtime closures, i.e. temporarily forbidding fishing in specific areas where the amount of unwanted catches was forecast to exceed a certain limit. In Kuwait, the shrimp trawling fishery successfully reduced the catch of unwanted species by introducing a spatial fishery closure in the Kuwait bay (Ye et al. 2000).

In the fishery studied, a temporal fishery closure might be an appropriate management strategy given 
the high seasonal pattern of discard ratios. The closure should include at least the fishing grounds inside the canyon, which is the area hosting the greatest diversity and the most vulnerable to the impact of fishing activities. A one-month fishery closure in winter is already in place in the three fishing grounds studied, and it aims to preserve the red shrimp juveniles. Our suggestion is that this closure should be prolonged for a few weeks in spring in order to address the discard issue at the canyon head and wall. The effectiveness of this measure for mitigating overall discards in the fishery should be monitored over time, considering the potential occurrence of unintended results such as fishing effort shifts and reduced catch of target species (O' Keefe et al. 2013). In fact, a spatio-temporal closure is not costless to the fishermen, as it might imply loss of fishing opportunities. Moreover, the canyon head and wall are the closest fishing grounds to the coast, so the cost of fuel for fishing trips is considerably reduced. On the other hand, submarine canyons are unique sites for the recruitment of many species (Stefanescu et al. 1994, Sardà and Cartes 1997, Tyler and Ramirez-Llodra 2002, Sardà et al. 2004, Ramirez-Llodra et al. 2010), which are threatened by anthropogenic activities and should be preserved in order to maintain their ecological value.

\section{ACKNOWLEDGEMENTS}

The authors would like to thank the Fishermen Association of Palamós and in particular the skipper Conrad Massaguer and the crew of the fishing vessel Nova Gasela for their invaluable support during sampling. We also thank Valerio Sbragaglia, Carol Doya and Milan Müller for their help in the field. We are grateful to Prof. Cardona for his comments and Carlos Dominguez and M. Teresa Farriols for their help on the data analysis. Finally, the EC Programme Science in Society EC FP7 (grant agreements 266544-GAP2 and 287600-PERSEUS), the FPU grant of the Spanish Ministry of Education and the Marine Stewardship Council are acknowledged for their financial support.

\section{REFERENCES}

Abelló P., Bertrand J.A., de Sola L.G., et al. 2002. Mediterranean marine demersal resources: The MEDITS international trawl survey (1994-1999). Sci. Mar. 66(Suppl. 2): 9-17. http://dx.doi.org/10.3989/scimar.2002.66s29

Auster P.J., Malatesta R.J., Langton R.W., et al. 1996. The impacts of mobile fishing gear on seafloor habitats in the Gulf of Maine (Northwest Atlantic): implications for conservation of fish populations. Rev. Fish. Sci. 4 (2): 185-202. http://dx.doi.org/10.1080/10641269609388584

Bas C., Macpherson E., Sardà F. 1984. Fishes and fishermen. The exploitable trophic levels. In: Margalef R. (ed.) Key Environments. Western Mediterranean. Pergamon Press, Oxford : 296-316.

Bellido J.M., Santos M.B., Pennino M.G., et al. 2011. Fishery discards and bycatch: solutions for an ecosystem approach to fisheries management? Hydrobiologia 670: 317-333. http://dx.doi.org/10.1007/s10750-011-0721-5

Bjørnar I. 1996. The Norwegian approach to reduce by-catch and avoid discards. Papers presented at the: technical consultation on reduction of wastage in fisheries, Tokyo, Japan, 28 october - 1 November 1996, FAO.

BOE (Boletín Oficial del Estado) de 27 de Mayo de 2013. Orden
AAA/923/2013 de 16 de Mayo, nº 126, Sec. III, Pág. 40016 (2013). http://www.boe.es/boe/dias/2013/05/27/pdfs/BOEA-2013-5555.pdf

Canals M., Puig P., Durrieu de Madron X., et al. 2006. Flushing submarine canyons. Nature 444: 354-357. http://dx.doi.org/10.1038/nature05271

Carbonell A., Alemany F., Merella P., et al. 2003. The by-catch of sharks in the western Mediterranena (Balearic Islands) trawl fishery. Fish. Res. 61: 7-18. http://dx.doi.org/10.1016/S0165-7836(02)00242-4

Cartes J.E. 1998. Dynamics of the Bathyal Benthic Boundary Layer in the northwestern Mediterranean: depth and temporal variations in macrofaunal - megafaunal communities and their possible connections within deep-sea trophic webs. Prog. Oceanogr. 41: 111-139. http://dx.doi.org/10.1016/S0079-6611(98)00018-4

Castriota L., Campagnuolo S., Andaloro F. 2001. Shrimp trawl fishery by-catch in the Straits of Sicily (central Mediterranean Sea). Scientific Council Research Documents of the Northwest Atlantic Fisheries Organization, Serial No. N4501, No 01/113.

Catchpole T.L., Gray T.S. 2010. Reducing discards of fish at sea: a review of European pilot projects. J. Environ. Manage. 91: 717-723.

http://dx.doi.org/10.1016/j.jenvman.2009.09.035

Catchpole T.L., Frid C.L.J., Gray T.S. 2005. Discards in the North Sea fisheries: causes, consequences and solutions. Mar. Policy 29: 421-430 http://dx.doi.org/10.1016/j.marpol.2004.07.001

Catchpole T.L., Feekings J.P., Madsen N., et al. 2013. Using inferred drivers of discarding behavior to evaluate discard mitigation measures. ICES J. Mar. Sci. 71(5): 1277-1285. http://dx.doi.org/10.1093/icesjms/fst170

Clarke K.R., Gorley R.N. 2006. PRIMER v6. User Manual/Tutorial. PRIMER-E, Plymouth.

Clarke K.R., Warwick R.M. 2001. Change in marine communities: an approach to statistical analysis and interpretation, 2nd edn. PRIMER-E, Plymouth.

Company J.B., Puig P., Sardà F., et al. 2008. Climate influence on deep sea populations. Plos One 3 (1): e1431. http://dx.doi.org/10.1371/journal.pone.0001431

Condie H.M., Grant A., Catchpole T.L. 2014. Incentivising selective fishing under a policy to ban discards; lessons from European and global fisheries. Mar. Policy 45: 287-292. http://dx.doi.org/10.1016/j.marpol.2013.09.001

De Juan S., Lo Iacono C., Demestre M. 2013. Benthic habitat characterization in soft-bottom continental shelves: integration of acoustic surveys, benthic samples and trawling disturbance. Estuar. Coast. Shelf. Sci. 117: 199-209. http://dx.doi.org/10.1016/j.ecss.2012.11.012

Edelist D., Sonin O., Golani D., et al. 2011. Spatiotemporal patterns of catch and discards of the Israeli Mediterranean trawl fishery in the early 1990s: ecological and conservation perspectives. Sci. Mar. 75(4): 641-652. http://dx.doi.org/10.3989/scimar.2011.75n4641

European Union. 2013. Regulation (EU) No 1380/2013 of the European Parliament and of the Council of 11th of December 2013 on the Common Fisheries Policy, amending Council Regulations (EC) No. 1954/2003 and (EC) and (EC) No 1224/2009 and repealing Council Regulations (EC) No. 2371/2002, (EC) No 639/2004 and Council Decision (EC) No. 2004/585/EC. Off. J. European Union 254: 22-61. http://dx.doi.org/10.3000/19770677.L_2013.354.eng

Farriols M.T., Ordines F., Hidalgo M., et al. 2015. N90 index: A new approach to biodiversity based on similarity and sensitive to direct and indirect fishing impact. Ecol. Indic. 52: 245-255. http://dx.doi.org/10.1016/j.ecolind.2014.12.009

García-Rivera S., Sánchez-Lizaso J.L., Bellido Millán J.M. 2015. A quantitative and qualitative assessment of the discard ban in European Mediterranean waters. Mar. Policy 53: 149-158. http://dx.doi.org/10.1016/j.marpol.2014.12.003

Heussner S., Calafat A., Palanques A. 1996. Quantitative and qualitative features of particle fluxes in the North-Balearic basin. In: Canals M., Casamor J.L., Cacho I., et al., (eds), EUROMARGE-NB Final Report, MAST II Programme, EU, vol. II, 41-66, Chapter 3.

Hilborn R. 2011. Future directions in ecosystem based fisheries management: a personal perspective. Fish. Res. 108: 235-239. http://dx.doi.org/10.1016/j.fishres.2010.12.030

IUCN 2014. The IUCN red list of threatened species. http://www. iucnredlist.org/ 
Jennings S., Kaiser M.J. 1998. The effects of fishing on marine ecosystems. Adv. Mar. Biol. 34: 201-352. http://dx.doi.org/10.1016/S0065-2881(08)60212-6

Johnsen J.P., Eliasen S. 2011. Solving complex fisheries management problems: What the EU can learn from the Nordic experiences of reduction of discards. Mar. Policy 35: 130-139. http://dx.doi.org/10.1016/j.marpol.2010.08.011

Kelleher K. 2005. Discards in the world's marine fisheries. An update. FAO, Rome. $131 \mathrm{pp}$.

Koslow J.A., Boehlert G.W., Gordon J.D.M., et al. 2000. Continental slope and deep-sea fisheries: implications for a fragile ecosystem. ICES J. Mar. Sci. 57: 548-557. http://dx.doi.org/10.1006/jmsc.2000.0722

Lleonart J., Maynou F. 2003. Fish stock assessment in the Mediterranean: state of the art. Sci Mar. 67(Suppl. 1): 37-49. http://dx.doi.org/10.3989/scimar.2003.67s137

Machias A., Vasilopoulou V., Vatsos D., et al. 2001. Bottom trawl discards in the northeastern Mediterranean Sea. Fish. Res. 53: 181-195. http://dx.doi.org/10.1016/S0165-7836(00)00298-8

Moranta J., Massutí E., Morales-Nin B. 2000. Fish catch composition of the deep-sea decapod crustacean fisheries in the Balearic Islands (western Mediterranean). Fish. Res. 45: 253-264. http://dx.doi.org/10.1016/S0165-7836(99)00119-8

O'Keefe C.E., Cadrin S.X., Stokesbury K.D.E. 2013. Evaluating effectiveness of time/area closures, quotas/caps, and fleet communications to reduce fisheries bycatch. ICES J. Mar. Sci. 71(5): 1286-1297. http://dx.doi.org/10.1093/icesjms/fst063

Pennino M.G., Muñoz F., Conesa D., et al. 2013. Modelling sensitive elasmobranch habitats. J. Sea Res. 83: 209-218. http://dx.doi.org/10.1016/j.seares.2013.03.005

Pennino M.G., Muñoz F., Conesa D., et al. 2014. Bayesian spatiotemporal discard model in a demersal trawl fishery. J. Sea Res. 90: $44-53$ http://dx doi.oro/10.1016/j.seares.2014.03.001

Puig P., Durrieu de Madron X., Salat J., et al. 2013. Thick bottom nepheloid layers in the western Mediterranean generated by deep dense shelf water cascading. Prog. Oceanogr. 111: 1-23. http://dx.doi.org/10.1016/j.pocean.2012.10.003

Ramirez-Llodra E., Ballesteros M., Company J.B., et al. 2008. Spatio-temporal variations in the diversity, biomass and abundance of bathyal invertebrates in the Catalan Sea (Western Mediterranean). Mar. Biol. 153: 297-309. http://dx.doi.org/10.1007/s00227-007-0805-y

Ramirez-Llodra E., Company J.B., Sardà F., et al. 2010. Megabenthic diversity patterns and community structure of the Blanes submarine canyon and adjacent slope in the Northwestern Mediterranean: a human overprint? Mar. Ecol. 31: 167-182. http://dx.doi.org/10.1111/j.1439-0485.2009.00336.x

Ramsay K., Kaiser M.J., Hughes R.N. 1998. Responses of benthic scavengers to fishing disturbance by towed gears in different habitats. J.Exp. Mar. Biol. Ecol. 224: 73-89. http://dx.doi.org/10.1016/S0022-0981(97)00170-6

Sánchez P., Demestre M., Ramón M., et al. 2000. The impact of otter trawling on mud communities in the NW Mediterranean. ICES J. Mar. Sci. 57: 1352-1358. http://dx.doi.org/10.1006/jmsc.2000.0928

Sánchez P., Demestre M., Martín P. 2004. Characterization of the discards generated by bottom trawling in the northwestern Mediterranean. Fish. Res. 67: 71-80. http://dx.doi.org/10.1016/j.fishres.2003.08.004

Sánchez P., Sartor P., Recasens L., et al. 2007. Trawl catch composition during different fishing intensity periods in two Mediterranean demersal fishing grounds. Sci. Mar. 71: 765-773. http://dx.doi.org/10.3989/scimar.2007.71n4765

Sardà F., Cartes J. 1997. Morphological features and ecological aspects of early juvenile specimens of the aristeid shrimp Aristeus antennatus (Risso, 116). Mar. Freshwater Res. 48: 73-77. http://dx.doi.org/10.1071/MF95043

Sardà F., Cartes J., Company J.B. 1994a. Spatio-temporal variations in megabenthos abundance in three different habitats on the Catalan deep-sea (Western Mediterranean). Mar. Biol. 120: 211-219.

\section{http://dx.doi.org/10.1007/BF00349681}

Sardà F., Cartes J., Norbis W. 1994b. Spatio-temporal structure of the deep-water shrimp Aristeus antennatus (Decapoda: Aristeidae) population in the Western Mediterranean. Fish. Bull. 92: 599-607.

Sardà F., Maynou F., Talló L. 1997. Seasonal and spatial mobility patterns of rose shrimp Aristeus antennatus in the Western Mediterranean: results of a long-term study. Mar. Ecol. Prog. Ser. 159: 133-141. http://dx.doi.org/10.3354/meps 159133

Sardà F., Company J.B., Castellón A. 2003. Intraspecific aggregation structure of a shoal of a Western Mediterranean (Catalan coast) deep-sea shrimp, Aristeus antennatus (Risso, 1816), during the reproductive period. J. Shellfish Res. 22: 569-579.

Sardà F., D’Onghia G., Politou C-Y., et al. 2004. Deep-sea distribution, biological and ecological aspects of Aristeus antennatus (Risso, 1816) in the Western and Central Mediterranean Sea. Sci. Mar. 68(Suppl. 3): 117-127. http://dx.doi.org/10.3989/scimar.2004.68s3117

Sardà F., Company J.B., Bahamon N., et al. 2009. Relationship between environment and the occurrence of the deep-water rose shrimp Aristeus antennatus (Risso, 1816) in the Blanes submarine canyon (NW Mediterranean). Progr. Oceanog. 82(4): 227-238.

http://dx.doi.org/10.1016/j.pocean.2009.07.001

Sardà F., Coll M., Heymans J.J., et al. 2013. Overlooked impacts and challenges of the new European discard ban. Fish. Fish. 16(1): 175-180. http://dx.doi.org/10.1111/faf.12060

Sartor P., Sbrana M., Reale B., et al. 2003. Impact of the deep-sea trawl fishery on demersal communities in the northern Tyrrhenian Sea (western Mediterranean). J. Northwest Atl. Fish. Sci. 31: 275-284.

STECF. 2006. Discards from community vessels report of the scientific, technical and economic committee for fisheries (STECF). Commission Staff Working Paper Brussels.

Stefanescu C., Morales-Nin B., Massutí E. 1994. Fish assemblages on the slope in the Catalan Sea (Western Mediterranean): influence of a submarine canyon. J. Mar. Biol. Assoc. U. K. 74: 499-512. http://dx.doi.org/10.1017/S0025315400047627

Stergiou K.I., Economou A., Papacostantinou C., et al. 1998. Estimates of discards in the Hellenic commercial trawl fishery. Rapp. Comm. Int. Expl. Sci. Mer Medit. 35: 490-491.

Tsagarakis K., Machias A., Giannoulaki M., et al. 2008. Seasonal and temporal trends in metrics of fish community for otter-trawl discards in a Mediterranean ecosystem. ICES J. Mar. Sci. 65: 539-550. http://dx.doi.org/10.1093/icesjms/fsn023

Tsagarakis K., Palialexis A., Vassilopoulou V. 2013. Mediterranean fishery discards: review of the existing knowledge. ICES J. Mar. Sci. 71: 1219-1234. http://dx.doi.org/10.1093/icesjms/fst074

Tudela S., Sardà F., Maynou F., et al. 2003. Influence of submarine canyons on the distribution of the deep-water shrimp, Aristeus antennatus (Risso, 1816) in the NW Mediterranean. Crustaceana $76(2): 217-225$ http://dx.doi.org/10.1163/156854003321824567

Tyler P.A., Ramirez-Llodra E. 2002. Larval and reproductive strategies on European continental margins. In: Billet D.S.M., Wefer G., Hebbeln D., et al. (eds), Ocean Margin Systems. Springer, Berlin. pp. 339-350. http://dx.doi.org/10.1007/978-3-662-05127-6 21

Uhlmann S.S., Van Helmond A.T.M., Stefansdottir E.K., et al. 2013. Discarded fish in European waters: general patterns and contrasts. ICES J. Mar. Sci. 71(5): 1235-1245. http://dx.doi.org/10.1093/icesjms/fst030

Vetter E.W., Dayton P.K. 1999. Organic enrichment by macrophythe deritus and abundance patterns of megafaunal populations in submarine canyons. Mar. Ecol. Prog. Ser. 186: 137-148. http://dx.doi.org/10.3354/meps186137

Ye Y., Alsaffar A.H., Mohammed H.M.A 2000. Bycatch and discards of the Kuwait shrimp fishery. Fish. Res. 45: 9-19. http://dx.doi.org/10.1016/S0165-7836(99)00105-8 